\title{
XLII. On a new kind of painting with the serum or watery part of the blood
}

\section{F. Carbonel M.D.}

To cite this article: F. Carbonel M.D. (1803) XLII. On a new kind of painting with the serum or watery part of the blood, Philosophical Magazine Series 1, 15:59, 240-245, DOI: 10.1080/14786440308676264

To link to this article: http://dx.doi.org/10.1080/14786440308676264

曲 Published online: 18 May 2009.

Submit your article to this journal $\lceil\pi$

Џll Article views: 2

Q View related articles $\square$ 
as low as poffible, both on account of their utility in our manufactories, and of the neceffity of maintaining a competition with the Englifh coals.

The carriage by the caufeways from Charleroi and Mons to Bruffels adds greatly to the price of thefe coals. A canal has been projected for uniting the Sambre towards Thuin with the fmall river of Senne; which would convey the coals of the mines in the neigbbourhood of Charleroi to Bruffels, and would thus form a communication with the Scheldt and Batavia, fo as to prevent the neceffity of land carriage.

This canal, valuable in this point of view, would be of utility alfo to the export trade of thefe countries in regard to the glafs and nails fent to Holland and to our own ports, and which are thence conveyed to the Indies.

It would be of utility alfo to government for tranfporting the timber of the Foreft of Souane, through which it would pafs.

To point out thefe improvements will, no doubt, be fufficient to induce government to pay ferious attention to them; but until new means of circulation be provided, it is of importance that the exifting roads thould be properly repaired.

I thall terminate this article by obferving, that it is the intereft of France to facilitate its commercial intercourfe with Holland, and particularly that which relates to the importation of our coals into that country : confequently, inftead of laying a duty on their exportation to the amount, as is faid, of 20 per cent., this branch of commerce ought to be entirely free. It would be good policy alfo to encourage by bounties the exportation of the coals of this department, efpecially when deftined for French ports in parts of our territory which cannot receive this fuel from the mines of the interior, and which if not fupplied by our mines would procure them from foreign countries.

[To be continued.]

XLII. On a new Kind of Painting with the Serum or watery Purt of the Blood. By F. CARBoneL, M.D. of Barcelona*. TH

$\mathrm{HE}$ advantages and utility of painting have at all times excited the emulation of profeffors and of artifs. The progrefs of this art, which imitates nature, bas fortunately correfponded to their wifhes; but its advancement would cer-

* From the Fuurnal de P.jygique, Ventore, an. ir. tainly 
tainly have been more rapid if artifts had been fooner made acquainted with the new chemiftry. This affertion is proved by the prefent difcovery.

The neceffity of painting furfaces of different kinds, their various fituations, and the complex circumftances which attend the application of colours, have given rife to the different kinds of painting which are known; fuch as painting in frefco, painting in fize, oil-painting, painting with milk, painting on porcelain, painting with wax, painting on glafs, \&c.

The journey of the king of Spain to Barcelona, and the preparation of the edifices deftined for the ufe of their majefties, afforded me an opportunity of folving a new problem in regard to this art. It was neceffary to difcover fome kind of painting of the common colour of ftone which might be able to refift rain, which fhould be unalterable in the fun, eafy to be applied on wond, and which fhould dry foon and exhale no bad odour; in a word, a painting equally durable with that in fize, and which thould have the property of being able to withftand the inclemency of the weather. The folubility of gelatin in water, the bad fmell of oil, the weak adhefion of milk of lime to wood, and its ready alteration by heat, made me fenfible that it would be impoffible to have recourfe to any of the known vehicles for fecuring the colouring matters. After fome examination I found that albumen * was the only fubftance which could anfwer the required conditions, on account of its infolubility in water, and the confiftence it acquires by combining with calcareous earths. This fubftance, prepared by the vital power in the animal organs, is found almoft pure in the white of an egg or albumen, and is found in combination in different animal fubftauces. But the great vifcidity of the white of an egg, the clots which are formed by its combination with lime, and particularly its dearnefs, made me give up all idea of employing it for painting a whole edifice.

I then conceived that the ferum of blood, the principal part of which confifts of albumen, would be attended with all the advantages of white of egg for the propofed end, without having any of its inconveniences. Chemical analyfis of animal fubitances, indeed, thows that the ferum of blond, commonly called the water of the blood, or, improperly, the lymph of the blood, is a kind of animal mucilage compored of albuminous or gelatinous fubftances in different propor-

* This painting wis much wanted for the buldge which joins the bor? de la Doune to the pa! +ce of the caprain-general, is no wher kind could be emplayed for fuar of injuring the queen's heaith.

Vol. XV. No. 59. 
tions, diffolved in an indeterminate quantity of water, conAtantly united to pure foda, which reduces the albuminous fubftance to an almoft faponaceous ftate. There is found alfo in the ferum phofphate of foda, of lime, and of ammonia. But thefe faline fubftances are not effential to this combination, fince they not only may vary in their proportions, but be wanting either in whole or in part; and even unite in the ferum to other falts, fuch as the muriate of potafh, the phofphate of magnefia, \&c., without the albuminous, alkaline, or gelatinous fubftance of the ferum being changed, or exhibiting different characteriftic properties.

This doctrine, received by all the celebrated modern chemifts, induced me to think that the albuminous fubftance of ferum, modified by its combination with gelatin and foda, ought to form with calcareous earth a compofition which would retain no more of that vifcidity and tenacity affumed by the mixture of the white of an egg and lime, than what might be neceffary for anfwering the propofed end.

Thefe reafons, and the low price of this liquid in large cities, foon induced me to try the effects of the ferum of blood with pulverized quicklime; and I found, with much fatisfaction, that my firft trials correfponded in every refpect to the hopes I had conceived.

\section{Praclice and Application of the new Kind of Painting.}

The preparation of this new kind of paint is eafy, and requires very little time. Nothing is neceffary but to pulverize the lime, and to dilute it in the ferum of blood until it forms a liquid of fufficient thicknefs for painting; which is then to be applied in the ufual manner. The colour which this compofition acquires is whitifh, and more or lefs thining, according to the purity of the ferum and the whitenefs of the lime. This earth may be employed either in the ftate of quick or cauftic lime reduced to powder, or well haked with a fmall quantity of water to leffen the adhefion of its integrant parts. It muft then be reduced to a fine powder, and be fifted through a clofe fieve. If kept for fome days, it is neceffary to preferve it in a clofe tub or earthen veffel, to prevent its combination with the carbonic acid and water of the atmofphere. The ferum is feparated from the curdled blood by decantation: but care mut be taken to thake the matter as little as poffible, and to fuffer it each time to remain at reft.

In this compofition two things only are to be obferved: the firt is, that ferum being a fluid highly fufceptible of corruption, it muft be employed the fame day it is feparated; or 
at furtheft the day following, provided it be kept in a cool place theltered from the contact of the air, efpecially during the fummer, when it alters much more eafily.

In cafe of doubt, infpection of the fluid alone may ferve to determine its quality; for the figns of its fermentation are very evident. This obfervation is applicable alfo to the colouring liquor, but in a lefs degree. It follow's from this circumftance, that the veffels which have been ufed for containing, preparing, or applying paint made with ferum ought to be wahed every day. The fecond precaution to be taken is, that as the re-action of the ferum and lime increafes in the courfe of time, as well as the denfity of the mixture, in order that it may be preferved in the neceffary ftate of fluidity, or to diminifh or increafe it according to the nature of the fubftances to be painted and the number of Itrata to be applied, another veffel filled with ferum mult be provided, to give to the colouring liquor the neceffary fluidity. It thence follows that the mixture muft be prepared as it is ufed.

Having affured myfelf of the fuccefsful and conftant effects of this kind of painting, I tried to mix it with different colouring fubftances, to render the application of the invention more general.

The well known re-action of animal fubftances and of lime on the metallic oxides, and particularly on thofe in which oxygen is united to the metal with little force, made me fufpect an alteration of fome colours when mixed with this liquid; an alteration naturally produced by the feparation of a part of the oxygen from the metallic oxides. On the other hand, the analogy which coloured chalks have with calcareous earth induced me to believe that their combination would be attended with the happieft refult. The oxides of lead, copper, and arfenic, indeed, undergo a fingular alteration in their refpective colours, when they are united with ferum and calcareous earth: but this is not the cafe with cobalt green; which on that account appears to me to be very proper for being ufed as a colouring matter in this new kind of painting. Thofe earths, however, called red, green, black, or yellow, which are of an argillo-calcareous nature, when mixed with thefe fubftances, may furnith different agreeable colours of a durability equal to the blneifh colour produced merely by the mixture of lime and of ferum.

I have however remarked, that the durability of this painting is confiderably altered when there is mixed with it a very large quantity of colouring earth, fuch as the black earth ufed for painting an iron colour, or the reprefentation of white marble with black fpots. To rcmedy this inconverience, no$\mathrm{R} 2$ thing 


\section{Painting witb tbe Serum or watery Part of the Blood.}

thing will be neceffary but to mix a little white of an egg with the ferum before it is united with the lime or the black earth. I muft here add, that wood painted in this manner may be polithed, and made to acquire a certain degree of luftre. In this cafe I have obferved that frefh fpermaceti may be fubftituted with advantage for the tallow or oil in which the rags employed for rubbing wood before it is polithed are commonly dipped. This kind of paint may be applied alfo with the fame fuccefs to earthen ware, lead, iron, cut ftone, \&c.

The circumftances which induced me to employ this new kind of painting, obliged me to make an extenfive ufe of it, without allowing me time to carry my operations any further. More than 300 arrobes $*$ of ferum were confumed in the courfe of a few days. In this manner we were able to paint not only the paffage and bridge of the king's palace, but alfo the windows and doors of the fame edifice, thofe of the magnificent building of the Exchange, the Place de Taureau, and many private houfes. The happy effects it produced, when expofed to the eyes of the public, are a fufficient proof that practice here perfectly correfponds with theory.

It is hardly neceffary to obferve, that the furfaces to be painted muft be fmooth; that the wood muft be covered with a ftratum of plafter; and that this painting muft not be applied over painting with oil or with turpentine, becaufe the heat would rrake it crack.

I propofe to continue the fmall number of trials $I$ have already made, to render the ufe of my difcovery more general. The following is the refult of thofe which I have hitherto been able to attempt.

In confequence of the vifcidity, adbefion, and fpeedy deficcation of this compofition, it may be employed in the fame manner as bitumen, to cement with great folidity broken articles of every kind. In this cafe it oppofes a ftrong refiftance to the action of fire, water, many of the gafes, and to vapour.

As ferum contains a large quantity of albuminous matter, having myfelf feparated from it nearly half its weight, it may be employed with advantage for clarifying fugar, wine, and other fubftances, in a more oconomical manner than by the white of an egg..

This new compofition may be employed alfo for covering the furface of damp walls intended to be painted in oil colours; taking care, however, to cover it with a coating of

* An arrobe weighs 25 or 26 pounds. 
On the Air-Furnaces employed in Iron Foundries. 245

plafter and glue, to prevent its re-action on the colouring parts of the painting.

The hardnefs of this fubftance, and its fufceptibility of receiving a polith, induce me to belicve that it might be employed on fucco, and for imitating it on walls and ceilings.

It may be ufed alfo for uniting water-conduits, and for cementing ftones of all dimenfions, and efpecially thofe which are put into wood caiflons for building under water.

It appears from different works, that the antients had conceived the idea of employing blood in the compofition of their cements and mortar; but the ufe of it in painting was before unknown. Befides, there was too great a diftance between this ufe of blood and that of ferum freed from the fibrous part and the colouring matter, to admit of any doubt that the principle of my difcovery is entirely my own.

It follows from what has been here faid, that this new kind of painting may be added to thofe already known, and that it may be called painting in jerum; that it is as eafily applied as prepared ; that the elements of it are common, and of little value; and that it unites in it all the advantages of painting in oil and in diftemper, without having any of their inconveniences.

XLIII. On the Kind of Air-Furnaces employed in Iron Foundries for cafting large Pieces of Ordnance, Sbafts for Mills, Cylinders, and otber beavy Articles. By Mr. David Mushet, of the Calder Iron Works *.

$\mathrm{T}$

HE furnaces about to be defcribed are employed for melting pig-iron with the flame of pit-coal. Fumaces of this kind are conftructed of various fizes according to cir cumftances. The fmall fizes will run down from feven to ten hundred weight, and are ufed in fmall foundries for what the trade call jobbing.

Fig. x. (Plate IV.) a ground plan of two large air-furnaces, and chimney for melting pig- or caft-iron with the flame of pit-coal.

The letters $A B C D$ point out the exterior dimenfions of the ftalk or chimney, which is firft erected, leaving two openings or arches into which the fore-part of the furnaces are afterwards built. The breadth of the chimney at the particular place which the plan exhibits is 16 feet from $A$ to $B$, and from $A$ to $D$ or from $B$ to $C 6$ feet 6 inches. The plan is drawn at that elevation where the flame enters the chimney

* Communicated by the Author.

$\mathrm{R}_{3}$ 